Godina IX | Broj 17 | Sveska 1/2021 | ISSN 2334-816X

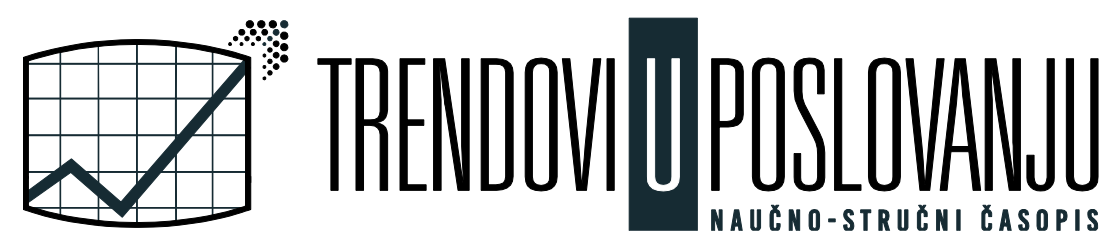

\author{
NEPRAVILNOSTI U SPROVOĐENJU POPISA \\ IMOVINE I OBAVEZA
}

\title{
IRREGULARITIES IN CONDUCTING THE LIST OF ASSETS AND LIABILITIES
}

Jakovljević Nemanja | Državna revizorska institucija, Beograd,Srbija| jakovljevic.i.nemanja@gmail.com>

\section{Sažetak}

Nepravilnosti koje se mogu javiti tokom pripreme i sprovođenja popisa imovine i obaveza mogu da imaju ozbiljne i višestruke implikacije na finansijske izveštaje entiteta i na njegov rezultat poslovanja. To je uslovljeno činjenicom da popis kao deo predzaključnih knjiženja predstavlja osnovu za svođenje knjigovodstvenog na stvarno stanje. Popisom se može utvrditi postojanje nedokumentovanih ekonomskih promena, za koje u trenutku njihovog nastanka nije postojao adekvatan dokument kojim bi se potvrdilo njihovo postojanje i njihov vrednosni uticaj na poslovanje entiteta. Nepravilno sprovođenje popisa može da bude uzrokovano i namernim radnjama koje su usmerene na prezentovanje netačnog stvarnog stanja u pokušaju da se u finansijskim izveštajima predstavi bolji rezultat poslovanja nego što stvarno jeste čime bi jedna interesna grupa ostvarila korist na štetu ostalih interesnih grupa. Iz tih razloga je važno razumeti nepravilnosti koje se javljaju prilikom popisa čime bi se predupredila i onemogućila njihova pojava u praksi.

\begin{abstract}
Irregularities that may occur during the preparation and conduct of the inventory of assets and liabilities may have serious and multiple implications for the entity's financial statements and its results of operations. This is conditioned by the fact that the inventory as a part of the pre-closing postings represents the basis for reducing the bookkeeping to the actual situation. The census can determine the existence of undocumented economic changes, for which at the time of their occurrence there was no adequate document to confirm their existence and their value impact on the operations of the entities. Improper conduct of the census can be sampled by intentional actions aimed at presenting incorrect facts in an attempt to present a better business result in the financial statements than it really is, which would benefit one stakeholder to the detriment of other stakeholders. For these reasons, it is important to understand the irregularities that occur during the census in order to prevent and disable their occurrence in practice.
\end{abstract}

Ključne reči: popis; imovina; obaveze i nepravilnost.

Keywords: inventory, assets, liabilities, irregularity.

JEL klasifikacija:HOO

DOI: $10.5937 /$ trendpos2101094J

UDK: 657.371

657.632

COBISS.SR-ID 41702921 


\section{Uvod}

Popis imovine i obaveza predstavlja proces utvrđivanja stvarnog stanja imovine i obaveza koji se prikazuje u izveštaju o popisu. Kod popisa je važno razlikovati popis kao formalni dokument u vidu Izveštaja o popisu od procesa popisivanja koji obuhvata sve radnje vezane za popis počev od pripremnih radnji, preko donošenja dokumenata i sprovođenja popisa do sastavljanja Izveštaja o popisu.

Popis imovine i obaveza kao aktivnost od velikog značaja za otvaranje poslovnih knjiga nosi veliku odgovornost lica koja učestvuju u njegovom sprovođenju ali i pored toga postoji veliki prostor za manipulisanje podacima i netačan prikaz stvarnog stanja utvrđenog popisom što u krajnjem slučaju može značajno da utiče na finansijski položaj subjekta iskazan u finansijskim izveštajima. Kumulativnim manipulacijama u višegodišnjem periodu implikacije na finansijske izveštaje se produbljuju, a razlika između knjigovodstvenog i stvarnog stanja može da se uveća do te mere da bude ozbiljno ugrožen kontinuitet poslovanja subjekta kao i primena osnovnih računovodstvenih načela. Iz gore pomenutog proizilazi i osnova problematike vršenja popisa koja se sastoji u nepoštovanju zakonodavnog okvira i nedovoljne ozbiljnosti u pristupanju samom procesu popisivanja. Popis je aktivnost koja zahteva dodatno angažovanje zaposlenih radnika i to najčešće preko redovnih aktivnosti, što je opcija koju velika većina zaposlenih nije spremna da prihvati iz različitih razloga, naročito ako se zna da angažovanje u popisu najčešće nije plaćeno. Uočljiv je nedostatak razumevanja ciljeva, suštine i značaja popisa kao i nedostatak motivacije za efikasno i efektivno sprovođenje popisa, a zaposleni koji nisu motivisani svoj posao neretko obavljaju mehanički, iz čega mogu da proisteknu različite nepravilnosti u celokupnoj proceduri popisivanja imovine i obaveza i svim pratećim dokumentima iz kojih se sastoji popis.

Sprovođenje popisa imovine i obaveza predstavlja veoma zahtevnu aktivnost, kako u pogledu složenosti procedure i značaja, tako i u pogledu angažovanja neophodnih resursa, a pre svega ljudskog faktora koji često može da bude presudan za kvalitet rezultata popisa.

Na teritoriji Autonomne pokrajine Vojvodina (u nastavku teksta AP Vojvodina) postoji 37 opština i 8 gradova koji su grupisani u 7 okruga. Svaka jedinica lokalne samouprave ima određeni broj direktnih i indirektnih korisnika koji sprovode popis. U nastavku rada biće prezentovani rezultati sprovedenog istraživanja koje se bazira na podacima iz Izveštaja o reviziji finansijskih izveštaja i Izveštaja o reviziji finansijskih izveštaja i pravilnosti poslovanja koje je sprovela Državna revizorska institucija Republike Srbije u jedinicama lokalne samouprave na teritoriji AP Vojvodina u periodu od 2012. do 2020. godine. Od ukupnog broja obuhvaćenih jedinica lokalne samouprave za posmatrani period samo u jednoj opštini Državna revizorska institucija nije vršila kontrolu popisa, a to je opština Vrbas. Kod svih ostalih jedinica lokalne samouprave je sprovedena revizija popisa imovine i obaveza bez fizičkog prisustva popisu od strane članova revizorskog tima. Za analizu su uzeti samo direktni korisnici sredstava budžeta jedinice lokalne samouprave, a to su: Opštinska uprava/ Gradska uprava; Skupština opštine/ grada; Predsednik opštine/ Gradonačelnik; Opštinsko/ gradsko veće i Opštinsko/ gradsko prvobranilaštvo.

Tokom posmatranog perioda zakonodavna regulativa koja se odnosi na popis imovine i obaveza kod korisnika budžetskih sredstava u koje spadaju i jedinice lokalne samouprave se nije značajno menjala, te stoga nema uticaja na rezultate sprovedenog istraživanja. Ona obuhvata Uredbu o budžetskom računovodstvu ("Službeni glasnik RS", br. 125/2003, 12/2006 i 27/2020), Zakon o budžetskom sistemu ("Službeni glasnik RS", br. 54/2009, 73/2010...72/2019), Pravilnik o načinu i rokovima vršenja popisa imovine i obaveza korisnika budžetskih sredstava Republike Srbije i usklađivanja knjigovodstvenog stanja sa stvarnim stanjem ("Službeni glasnik RS", br. 33/2015 i 101/2018) i Uputstvo o organizaciji i računovodstvenom obuhvatanju popisa imovine i obaveza budžetskih korisnika uključenih u konsolidovani račun trezora Autonomne pokrajine Vojvodine date na korišćenje drugim pravnim licima ("Službeni list AP Vojvodine", br. 49/2014, 51/2014, 3/2015 i 48/2015). 
Cilj istraživanja je da se izdvoje i analiziraju sve nepravilnosti i da se grupišu na način da se izdvoje one nepravilnosti koje se javljaju kod najvećeg broja jedinica lokalne samouprave, kao i da se sve jedinice lokalne samouprave na teritoriji AP Vojvodina grupišu i ocene brojevima od 1 do 5 u skladu sa brojem uočenih nepravilnosti i stepenom kvaliteta sprovedenog popisa.

Polazi se od osnovne hipoteze da se popis imovine i obaveza kod jedinica lokalne samouprave ne sprovodi u potpunosti na pravilan način u sladu sa zakonodavnom i profesionalnom regulativom. Nepravilnosti koje se mogu javiti tokom pripreme i sprovođenja popisa imovine i obaveza mogu da imaju ozbiljne i višestruke implikacije na finansijske izveštaje entiteta i na njegov rezultat poslovanja. To je uslovljeno činjenicom da popis kao deo predzaključnih knjiženja predstavlja osnovu za svođenje knjigovodstvenog na stvarno stanje. Nepravilno sprovođenje popisa može da bude uzrokovano i namernim radnjama koje su usmerene na prezentovanje netačnog stvarnog stanja u pokušaju da se u finansijskim izveštajima predstavi bolji rezultat poslovanja nego što stvarno jeste čime bi jedna interesna grupa ostvarila korist na štetu ostalih interesnih grupa. Iz tih razloga je važno razumeti nepravilnosti koje se javljaju prilikom popisa čime bi se predupredila i onemogućila njihova pojava u praksi.

Radi ocene uspešnosti sprovođenja popisa, primenjuje se komparativna analiza izdvojenih nepravilnosti uzorkovanih jedinica lokalne samouprave. Koriste se metode sinteze, analize, dedukcije i indukcije u kojima se polazeći od osnovnih pojednostavljenih pretpostavki dolazi do formulisanja opštih zaključaka.

Rezultati ovog rada su propraćeni i tabelarnim i grafičkim prikazima dobijenih rezultata sprovedenog istraživanja.

\section{Tok sprovođenja popisa}

Tok sprovođenja popisa se sastoji od prethodnih radnji, donošenja propratnih dokumenata, sprovođenja fizičkog popisa i sastavljanja Izveštaja o popisu, usvajanja Izveštaja o popisu i sprovođenja korektivnih knjiženja, čime se postiže usaglašenost knjigovodstvenog sa stvarnim stanjem utvrđenim popisom.

Predpopisne radnje se na prvom mestu odnose na donošenje Pravilnika kojim se regulišu pitanja koja se odnose na popis. Ovakav Pravilnik se ne donosi svake godine, već kada se jednom donese, kasnije se samo ažurira u skladu sa promenama relevantnih propisa. Pored donošenja Pravilnika predpopisne radnje obuhvataju i usklađivanje poslovnih knjiga, odnosno usklađivanje dnevnika sa glavnom knjigom i pomoćnim knjigama i sređivanje prostorija, dokumenata i sredstava koji će biti predmet popisa ili će biti upotrebljavani u procesu popisivanja.

Popis započinje donošenjem odluke o sprovođenju popisa za poslovnu godinu od strane nadležnog organa kojom se definiše predmet popisa. Neretko je u okviru odluke o popisu naveden i sastav popisnih komisija, a opet on može da bude određen i posebnim Rešenjem o formiranju popisnih komisija. Ukoliko je određeno da popis sprovodi više od jedne komisije onda je neophodno formirati i centralnu popisnu komisiju, čiji će zadatak biti da kontroliše i objedini rad ostalih popisnih komisija. Svaka komisija je dužna da donese svoj plan rada. Takođe nadležni organ donosi i Uputstvo o sprovođenju popisa kojim su bliže opisane procedure popisa i predmet popisa.

Članovi popisne komisije pristupaju sprovođenju popisa na osnovu plana, uputstva i dobijenih popisnih lista od strane knjigovodstva u kojima se nikako ne sme nalaziti knjigovodstveno stanje. Ono će biti upisano kasnije, nakon što članovi popisne komisije izvrše popis i utvrde i u popisne liste unesu stvarno stanje.

Kada se završi sprovođenje popisa, popisne liste se sumiraju i sastavlja se Izveštaj o popisu koji se u definisanom roku predaje nadležnom organu na razmatranje i usvajanje. Nadležni organ saziva sednicu na kojoj se razmatra sadržina Izveštaja o popisu i na kojoj se donosi Odluka o 
usvajanju Izveštaja o popisu. U praksi se pokazalo da nadležni organ upotrebljava jednu od tri mogućnosti kod usvajanja Izveštaja o popisu. Prva je da se Izveštaj usvoji u potpunosti na način na koji je i dostavljen. Druga mogućnost je da se Izveštaj usvoji uz korekcije koje se kreću u pravcu usvajanja primedbi nadležnog organa. Treća i poslednja mogućnost je da se Izveštaj o popisu odbaci kao neispravan i da se naredi ponovo sprovođenje popisa sa potpuno novim članovima popisne komisije. Ukoliko je popisom utvrđeno postojanje razlika, popisna komisija predlaže način na koji će one da se otklone putem korektivnih knjiženja kojima će se sprovesti svođenje knjigovodstvenog na stvarno stanje. Nadležni organ usvaja način otklanjanja razlika i predlaže drugi način na koji će se otkloniti utvrđene razlike. Nakon završetka sednice sastavlja se tekst Odluke o usvajanju Izveštaja o popisu koji potpisuje predstavnik nadležnog organa i Odluka se dostavlja računovodstvenoj službi koja sprovodi korektivna knjiženja obično pod jednim nalogom za knjiženje koji se naslovljava kao sprovođenje odluke o popisu.

Nakon što nadležni organ usvoji izveštaj, knjigovodstvena služba pristupa sprovođenju korektivnih knjiženja ukoliko ima potrebe za tim, a u velikoj većini slučajeva ima. Sprovedenim korektivnim knjiženjima završen je tok popisa i ukoliko je popis sproveden na ispravan način onda kao rezultat sprovedenog popisa imamo da knjigovodstveno stanje odgovara stvarnom stanju imovine i obaveza.

\section{Metodologija istraživanja}

Trebalo bi da bude svedena na minimum. Opšte prihvaćene mere i njihove jedinice mogu biti korišćene bez posebnog definisanja.

Nepravilnosti u sprovođenju popisa kod direktnih korisnika budžeta jedinica lokalne samouprave na teritoriji autonomne pokrajine Vojvodina analizirane su uvidom u Izveštaje Državne revizorske institucije koja je u periodu od 2012. do 2020. godine izvršila reviziju popisa bez fizičkog prisustvovanja popisu kod 44 od ukupno 45 jedinica lokalne samouprave koje su bile predmet posmatranja.

Istraživanje je podeljeno u dva dela. U prvom delu su izdvojene sve uočene nepravilnosti, koje su poređene po redosledu koji prati tok sprovođenja popisa, nakon čega su izdvojene one nepravilnosti koje se javljaju kod većeg broja korisnika. Na kraju je izdvojeno pet ključnih nepravilnosti koje su u okviru ovog rada prezentovane u tabelarnom prikazu (tabela broj 1).

U drugom delu istraživanja u skladu sa dobijenim rezultatima sve jedinice lokalne samouprave su ocenjene ocenama od 1 do 5 prema broju nepravilnosti koje su kod njih uočene u odnosu na ukupan broj ključnih nepravilnosti. Pretpostavke od kojih se pošlo su da nije bilo promena u zakonskim propisima koje su značajnije uticale na tok sprovođenja popisa, da su članovi revizorskih timova koji su vršili reviziju popisa svoj posao obavljali dosledno, savesno, nezavisno i u skladu sa zakonodavnim i profesionalnim okvirom.

Od ukupnog broja analiziranih jedinica lokalne samouprave kod 5 je revizija popisa vršena u 2012. godini, kod 1 u 2013. godini, kod 7 u 2014. godini, kod 3 u 2015. godini, kod 7 u 2016. godini, kod 7 u 2017. godini, kod 3 u 2018. godini, kod 7 u 2019. godini, kod 4 u 2020. godini i kod 1 jedinice lokalne samouprave nije vršena revizija popisa imovine i obaveza.

Kod onih jedinica lokalne samouprave kod kojih je Državna revizorska institucija u posmatranom periodu vršila kontrolu popisa više od jednog puta, uzeti su podaci koji se odnose na najskoriju reviziju popisa.

Istraživanje je sprovedeno komparativnom analizom dobijenih podataka, nakon čega je izvršeno njihovo grupisanje u skladu sa stepenom značajnosti nepravilnosti i brojem javljanja. Dobijeni rezultati su prikazani u okviru tabela i grafikona i formirana je mapa autonomne pokrajine Vojvodina sa prikazom svih jedinica lokalne samouprave i njihovim ocenama koje su dobile za kvalitet sprovedenog popisa. 


\section{Rezultati i diskusija}

Tokom prvog dela istraživanja koji se odnosio na izdvajanje svih uočenih nepravilnosti i njihovo sortiranje po redosledu koji prati tok sprovođenja popisa, izdvojeno je ukupno 27 različitih vrsta nepravilnosti, a ukupan broj uočenih nepravilnosti kod svih posmatranih jedinica lokalne samouprave utvrđen je u iznosu od 234 nepravilnosti, što je prikazano u Tabeli broj 1.

Prvih 9 nepravilnosti se javlja kod više od 10 jedinica lokalne samouprave što je značajan broj s' obzirom da je posmatrano ukupno 45 jedinica lokalne samouprave. Nepravilnost koja se javlja kod najvećeg broja posmatranih jedinica lokalne samouprave se odnosi na to da nije popisana sva imovina. Uzroci koji su doveli do toga mogu su zaista različiti, a neki od njih bi mogli da budu da lica koja su odgovorna za popis ne razumeju šta sve obuhvata imovina koja je predmet popisa; da imovina u poslovnim knjigama nije jasno klasifikovana ili da predmeti imovine nisu jasno obeleženi inventarskim brojevima čime je došlo do zabune članova popisne komisije. Svakako s obzirom na tako veliku pojavu nepravilnosti uočljiva je nezainteresovanost jedinica lokalne samouprave da popišu svu imovinu, što za sobom povlači sumnju da jedinice lokalne samouprave na teritoriji AP Vojvodina ne upravljaju imovinom na efikasan i efektivan način čime se ostavlja prostor za manipulacije i prevarne radnje od strane zaposlenih i ostalih lica. Ovo je naročito opasno ako znamo da jedinice lokalne samouprave raspolažu velikim površinama objekata i zemljišta koje su značajne vrednosti u poslovnim knjigama.

Druga najčešća nepravilnost se odnosi na to da izveštaj o popisu ne sadrži stvarno i knjigovodstveno stanje i utvrđene razlike. Ova nepravilnost se javlja kod 25 jedinica lokalne samouprave, što je više od polovina od ukupnog broja. Ovo je bilo obavezno svakim važećim Pravilnikom o popisu u posmatranom periodu, pa tako i trenutno važećim čiji član 11. stav 2. glasi: „Po izvršenom popisu, popisna komisija sačinjava izveštaj o izvršenom popisu, koji obavezno sadrži: stvarno i knjigovodstveno stanje imovine i obaveza; razlike između stvarnog stanja utvrđenog popisom i knjigovodstvenog stanja; predlog načina rešavanja utvrđenih razlika (manjkova i viškova, način nadoknađivanja manjkova i evidentiranje viškova, kao i način za rešavanje pitanja imovine koja nije više za upotrebu); primedbe i objašnjenja radnika koji rukuju imovinom, odnosno koji su zaduženi materijalnim i novčanim sredstvima (o utvrđenim razlikama), kao i druge primedbe i predloge popisne komisije u vezi sa popisom, uz koji se prilaže popisna lista i dokumentacija koja je služila za sastavljanje popisne liste" [1] .

Sledeća nepravilnost se odnosi na to da nije izvršeno usaglašavanje poslovnih knjiga pre otpočinjanja popisa ili da je usaglašavanje delimično izvršeno, odnosno da postoji razlika između dnevnika, glavne knjige i pomoćnih knjiga. Ova nepravilnost se javlja kod 21 jedinice lokalne samouprave, što je gotovo polovina od ukupnog broja.

Naredne tri nepravilnosti se javljaju kod 17 jedinica lokalne samouprave, a odnose se na to da nema vrednosnih popisnih lista, odnosno da u popisne liste nisu unete cene i da samim tim nije obračunata vrednost; da nisu popisane sve obaveze i da pomoćne knjige ne sadrže sve bitne elemente.

Na kraju još dve nepravilnosti se javljaju kod više kod 10 ili više jedinica lokalne samouprave, a to su da je članovima popisne komisije bio dostupan podatak o količini kod 11 jedinica i da popisne komisije nisu sačinile plan rada pre početka popisa kod 10 jedinica.

Ostale nepravilnosti se javljaju kod manje od 10 jedinica lokalne samouprave. 
Tabela broj 1. Nepravilnosti utvrđene revizijom popisa kod jedinica lokalne samouprave na teritoriji autonomne pokrajine Vojvodina

\begin{tabular}{|c|c|c|}
\hline R.b. & Opis nepravilnosti & $\begin{array}{l}\text { Broj jedinica } \\
\text { lokalne } \\
\text { samouprave } \\
\text { kod kojih je } \\
\text { uočena } \\
\text { nepravilnost }\end{array}$ \\
\hline 1 & Nije popisana sva imovina & 34 \\
\hline 2 & Izveštaj o popisu ne sadrži stvarno i knjigovodstveno stanje i razlike & 25 \\
\hline 3 & Nije izvršeno usaglašavanje poslovnih knjiga pre otpočinjanja popisa & 21 \\
\hline 4 & $\begin{array}{l}\text { Nije izvršeno usaglašavanje sa svim dužnicima/poveriocima pre } \\
\text { otpočinjanja popisa }\end{array}$ & 20 \\
\hline 5 & Nema vrednosnih popisnih lista - U popisne liste nisu unete cene & 17 \\
\hline 6 & Nisu popisane sve obaveze & 17 \\
\hline 7 & Pomoćne knjige ne sadrže bitne elemente & 17 \\
\hline 8 & Članovima popisne komisije je bio dostupan podatak o količini & 11 \\
\hline 9 & Nisu sačinili plan rada pre početka popisa & 10 \\
\hline 10 & $\begin{array}{l}\text { Nema naturalnih popisnih lista - U popisne liste nije uneto naturalno } \\
\text { stanje }\end{array}$ & 9 \\
\hline 11 & $\begin{array}{l}\text { Imovina drugih korisnika i data imovina nisu popisane na posebnim } \\
\text { listama ili nisu popisane uopšte }\end{array}$ & 8 \\
\hline 12 & Popis nepokretnosti nije izvršen obilaskom nepokretnosti & 6 \\
\hline 13 & $\begin{array}{l}\text { Inventarski brojevi nisu u potpunosti adekvatno dodeljeni svim } \\
\text { sredstvima }\end{array}$ & 5 \\
\hline 14 & Nije donet interni akt kojim je regulisano pitanje popisa & 4 \\
\hline 15 & Nije utvrđen stepen dovršenosti investicija & 4 \\
\hline 16 & Odluka o usvajanju izveštaja nije doneta u roku ili nije doneta uopšte & 4 \\
\hline 17 & Akt o obrazovanju popisne komisije nije donet u roku & 3 \\
\hline 18 & Popisne liste nisu potpisane od strane svih članova popisne komisije & 3 \\
\hline 19 & U popisne liste nije uneta jedinica mere & 3 \\
\hline 20 & Akta koja su vezana za popis nemaju datum i delovodni broj & 2 \\
\hline 21 & Izveštaj o popisu nije donet u roku & 2 \\
\hline 22 & Nije doneta odluka o rashodovanju i postupanju sa viškom/manjkom & 2 \\
\hline 23 & Nisu izvršena korektivna knjiženja & 2 \\
\hline 24 & $\begin{array}{l}\text { U poslovnim knjigama evidentirane su nepokretnosti na osnovu } \\
\text { podataka preuzetih iz registra koje vodi Republički geodetski zavod, a } \\
\text { da prethodno nije utvrđen imovinsko pravni status tih nepokretnosti }\end{array}$ & 2 \\
\hline 25 & Članovi popisne komisije su lica koja su odgovorna za predmet popisa & 1 \\
\hline 26 & $\begin{array}{l}\text { Oprema visoke vrednost je evidentirana i popisana kao sitan inventar } \\
\text { jer ne postoji interni akt kojim je definisano šta spada u koje sredstvo }\end{array}$ & 1 \\
\hline 27 & Popisne liste nisu potpisane od strane odgovornog lica & 1 \\
\hline & & 234 \\
\hline
\end{tabular}

Tokom drugog dela istraživanja u skladu sa dobijenim rezultatima sve jedinice lokalne samouprave su ocenjene ocenama od 1 do 5 prema broju nepravilnosti koje su kod njih uočene u odnosu na ukupan broj ključnih nepravilnosti.

Kao ključne nepravilnosti su izdvojene sledeće nepravilnosti: pre početka popisa nije izvršeno usklađivanje poslovnih knjiga; nije popisana sva imovina; nisu popisane sve obaveze, izveštaj o popisu ne sadrži stvarno i knjigovodstveno stanje i utvrđene razlike; nije izvršeno usaglašavanje sa svim dužnicima/ poveriocima. 
Na osnovu odabranih ključnih nepravilnosti formirana je skala od 1 do 5 i to na način da su ocene 0 i 1 dobile one jedinice lokalne samouprave koje popis ili nije sprovele uopšte ili su ga sprovele na nezadovoljavajući način. Kod ovih jedinica lokalne samouprave je potrebno izvršiti vanredni popis. Ocenu 2 su dobile jedinice kod kojih je loše sproveden. Kod njih je potrebno hitno preduzeti radnje kojima će se poboljšati sprovođenje popisa. Ocenu 3 su dobile jedinice lokalne samouprave kod kojih je popis sproveden na dobar način. Kod njih je takođe potrebno preduzeti radnje kojima će se poboljšati sprovođenje popisa. Ocenu 4 su dobile jedinice lokalne samouprave kod kojih je popis sproveden na veoma dobar način.

Slika broj 1. Preovlađujuće ocene kod jedinica lokalne samouprave

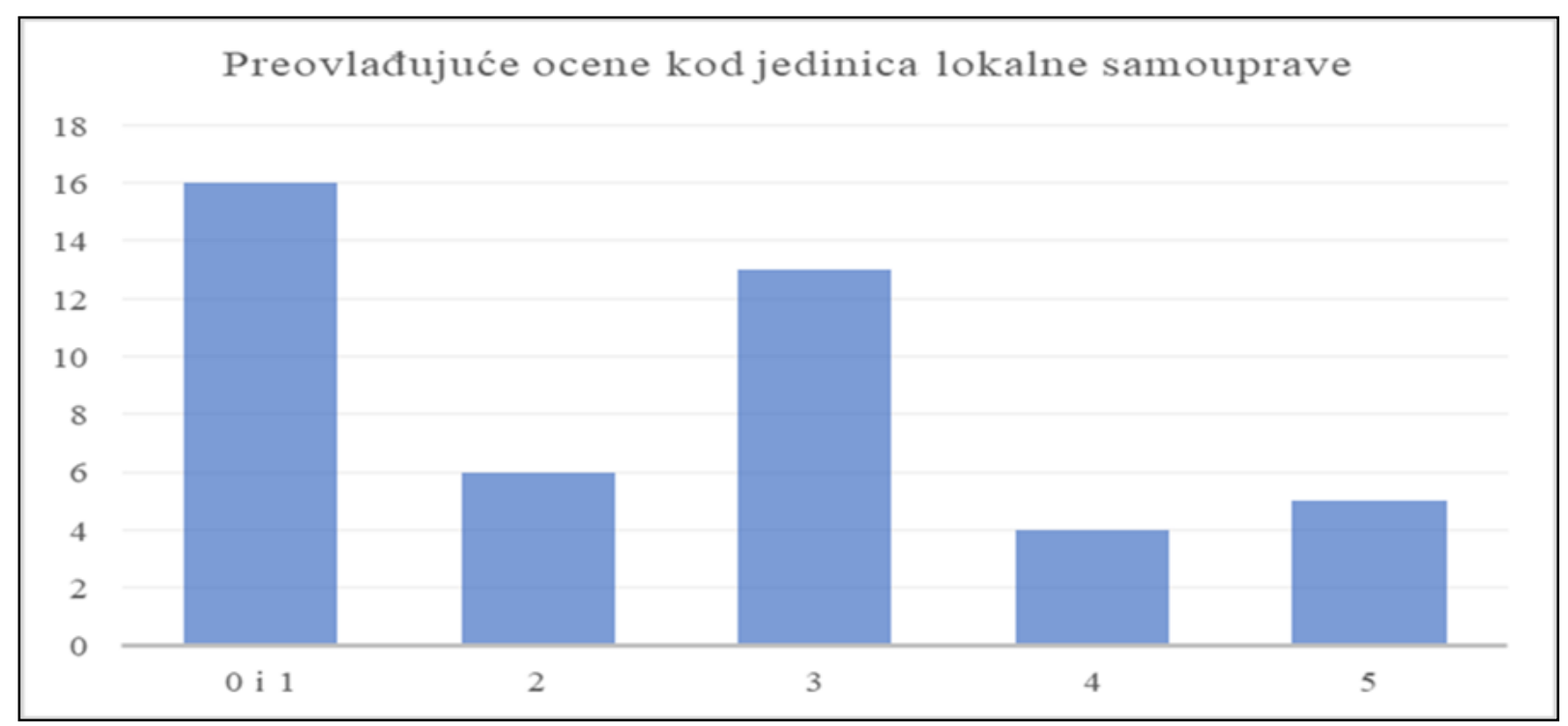

Kod njih je potrebno izvršiti kontrolu popisa i ispraviti uočene nedostatke Ocenu 5 su dobile jedinice lokalne samouprave kod kojih je popis sproveden na odličan način. Kod njih je potrebno redovno pratiti izmene u propisima i zadržati visok stepen sprovođenja popisa uz poboljšanja gde je to moguće. Ovakvim dodeljivanjem ocena kao rezultat istraživanja se dobija da od ukupnog broja analiziranih jedinica lokalne samouprave čak 16 je dobilo ocenu 0 ili 1 što znači da je kod njih potrebno izvršiti vanredni popis. 6 jedinica lokalne samouprave je dobilo ocenu 2, 13 je dobilo ocenu 3, 4 je dobilo ocenu 4 i 5 je dobilo ocenu 5 . Ukupan broj jedinica lokalne samouprave kod kojih je potrebno preduzeti radnje na kojima će se poboljšati sprovođenje popisa je velikih 35 od posmatranih 45 uz izuzeće jedne jedinice lokalne samouprave. To predstavlja skoro 78\% ukupnog broja, a to je podatak koji zabrinjava i koji postavlja pitanje zašto jedinice lokalne samouprave, odnosno direktni korisnici sredstava njihovog budžeta ne sprovode popis na pravilan način i u skladu sa zakonodavnom i profesionalnom regulativom? Zašto se izbegava popisivanje celokupne imovine i celokupnih obaveza? I zašto Izveštaji o popisu nisu jasni i transparentni? Samo kod dve jedinice lokalne samouprave nije uočena nijedna nepravilnost (kod obe je revizija popisa vršena 2020.).

Tabela broj 2. Pet najčešćih nepravilnosti i ocena istraživača

\begin{tabular}{|c|l|c|c|c|c|c|c|c|c|}
\hline 1 & 2 & 3 & 4 & 5 & 6 & 7 & 8 & 9 & 10 \\
\hline 1 & Sombor & 2018 & da & da & da & ne & ne & 4 & 3 \\
\hline 2 & Apatin & 2015 & ne & ne & da & ne & ne & 7 & 1 \\
\hline 3 & Odžaci & 2016 & da & ne & ne & da & da & 8 & 3 \\
\hline 4 & Kula & 2013 & da & ne & ne & ne & da & 4 & 2 \\
\hline 5 & Subotica & 2018 & da & da & da & da & da & 0 & 5 \\
\hline 6 & Bačka Topola & 2014 & ne & ne & da & ne & ne & 7 & 1 \\
\hline 7 & Mali Iđoš & 2014 & ne & ne & ne & ne & ne & 7 & 0 \\
\hline
\end{tabular}




\begin{tabular}{|c|c|c|c|c|c|c|c|c|c|}
\hline 8 & Kanjiža & 2016 & ne & ne & da & ne & da & 8 & 2 \\
\hline 9 & Novi Kneževac & 2011 & da & ne & da & da & ne & 3 & 3 \\
\hline 10 & Senta & 2016 & ne & ne & da & ne & ne & 6 & 1 \\
\hline 11 & Ada & 2015 & ne & ne & da & ne & ne & 9 & 1 \\
\hline 12 & Čoka & 2016 & ne & ne & ne & ne & $\mathrm{da}$ & 7 & 1 \\
\hline 13 & Kikinda & 2018 & da & ne & da & da & da & 2 & 4 \\
\hline 14 & Bečej & \multicolumn{8}{|c|}{ nije vršena revizija popisa } \\
\hline 15 & Srbobran & 2015 & ne & ne & da & ne & $\mathrm{da}$ & 10 & 2 \\
\hline 16 & Vrbas & 2013 & ne & ne & ne & ne & ne & 8 & 0 \\
\hline 17 & Bač & 2015 & da & da & da & da & $\mathrm{da}$ & 4 & 5 \\
\hline 18 & Bačka Palanka & 2013 & ne & ne & ne & ne & ne & 8 & 0 \\
\hline 19 & Bački Petrovac & 2011 & ne & ne & ne & ne & $\mathrm{da}$ & 5 & 1 \\
\hline 20 & Beočin & 2017 & da & ne & da & da & $\mathrm{da}$ & 4 & 4 \\
\hline 21 & Novi Sad & 2019 & ne & ne & da & da & da & 5 & 3 \\
\hline 22 & Sremski Karlovci & 2017 & ne & da & da & da & ne & 7 & 3 \\
\hline 23 & Titel & 2019 & ne & \begin{tabular}{|l|l|} 
ne \\
\end{tabular} & ne & da & ne & 7 & 1 \\
\hline 24 & Temerin & 2019 & $\mathrm{da}$ & da & da & $\mathrm{da}$ & $\mathrm{da}$ & 0 & 5 \\
\hline 25 & Žabalj & 2016 & da & ne & da & ne & da & 4 & 3 \\
\hline 26 & Novi Bečej & 2015 & ne & ne & ne & ne & ne & 10 & 0 \\
\hline 27 & Zrenjanin & 2018 & da & ne & ne & ne & da & 4 & 2 \\
\hline 28 & Nova Crnja & 2019 & $\mathrm{da}$ & ne & da & $\mathrm{da}$ & ne & 5 & 3 \\
\hline 29 & Žitište & 2011 & ne & ne & ne & ne & ne & 5 & 0 \\
\hline 30 & Sečanj & 2015 & da & ne & da & ne & $\mathrm{da}$ & 8 & 3 \\
\hline 31 & Šid & 2013 & da & ne & ne & da & da & 5 & 3 \\
\hline 32 & Sremska Mitrovica & 2018 & ne & da & da & ne & $\mathrm{da}$ & 4 & 3 \\
\hline 33 & Irig & 2015 & da & ne & da & da & ne & 5 & 3 \\
\hline 34 & Ruma & 2013 & ne & da & da & ne & $\mathrm{da}$ & 5 & 3 \\
\hline 35 & Inđija & 2012 & da & ne & da & ne & ne & 5 & 2 \\
\hline 36 & Stara Pazova & 2013 & ne & ne & da & ne & da & 6 & 2 \\
\hline 37 & Pećinci & 2011 & ne & ne & ne & ne & ne & 5 & 0 \\
\hline 38 & Opovo & 2017 & $\mathrm{da}$ & ne & da & $\mathrm{da}$ & $\mathrm{da}$ & 2 & 4 \\
\hline 39 & Kovačica & 2014 & da & da & ne & da & da & 1 & 4 \\
\hline 40 & Pančevo & 2018 & ne & ne & ne & ne & ne & 5 & 0 \\
\hline 41 & Alibunar & 2011 & da & ne & da & da & ne & 4 & 3 \\
\hline 42 & Plandište & 2016 & ne & ne & ne & ne & ne & 6 & 0 \\
\hline 43 & Vršac & 2018 & da & da & da & da & da & 5 & 5 \\
\hline 44 & Kovin & 2013 & da & da & da & da & $\mathrm{da}$ & 1 & 5 \\
\hline \multirow[t]{3}{*}{45} & Bela Crkva & 2016 & ne & ne & ne & ne & da & 9 & \begin{tabular}{|l|l}
1 \\
\end{tabular} \\
\hline & Ukupno ne: & 21 & 10 & 27 & 18 & 24 & \multirow{2}{*}{234} & \\
\hline & Ukupno da: & 23 & 34 & 17 & 26 & 20 & & & \\
\hline \multicolumn{10}{|c|}{ Legenda } \\
\hline $\begin{array}{l}\text { Broj } \\
\text { ocene }\end{array}$ & \multicolumn{9}{|c|}{ Opis } \\
\hline 0 i 1 & \multicolumn{9}{|c|}{$\begin{array}{l}\text { Popis ili nije sproveden uopšte ili je sproveden na nezadovoljavajući način - potrebnc } \\
\text { je izvršiti vanredni popis }\end{array}$} \\
\hline 2 & \multicolumn{9}{|c|}{$\begin{array}{l}\text { Popis je loše sproveden - potrebno je hitno preduzeti radnje kojima će se poboljšati } \\
\text { sprovođenje popisa }\end{array}$} \\
\hline 3 & \multicolumn{9}{|c|}{$\begin{array}{l}\text { Popis je sproveden na dobar način - potrebno je preduzeti radnje kojima će se } \\
\text { poboljšati sprovođenje popisa }\end{array}$} \\
\hline
\end{tabular}




\begin{tabular}{|l|l|}
\cline { 2 - 2 } 4 & $\begin{array}{l}\text { Popis je sproveden na veoma dobar način - potrebno je izvršiti kontrolu popisa i ispraviti } \\
\text { uočene nedostatke }\end{array}$ \\
\hline 5 & $\begin{array}{l}\text { Popis je sproveden na odličan način - potrebno je redovno pratiti izmene u propisima i } \\
\text { zadržati visok stepen sprovođenja popisa uz poboljšanja gde je to moguće }\end{array}$ \\
\hline $\begin{array}{l}\text { Broj } \\
\text { kolone }\end{array}$ & \multicolumn{1}{|c|}{ Opis } \\
\hline 1 & Redni broj \\
\hline 2 & Naziv Opštine/Grada \\
\hline 3 & Godina za koju je vršena revizija popisa \\
\hline 4 & Da li je pre početka popisa izvršeno usklađivanje poslovnih knjiga? \\
\hline 5 & Da li je popisana sva imovina? \\
\hline 6 & Da li su popisane sve obaveze? \\
\hline 7 & Da li izveštaj o popisu sadrži stvarno i knjigovodstveno stanje i utvrđene razlike? \\
\hline 8 & Da li je izvršeno usaglašavanje sa svim dužnicima/ poveriocima? \\
\hline 9 & Ukupan broj utvrđenih nepravilnosti \\
\hline 10 & Ocena istraživača \\
\hline
\end{tabular}

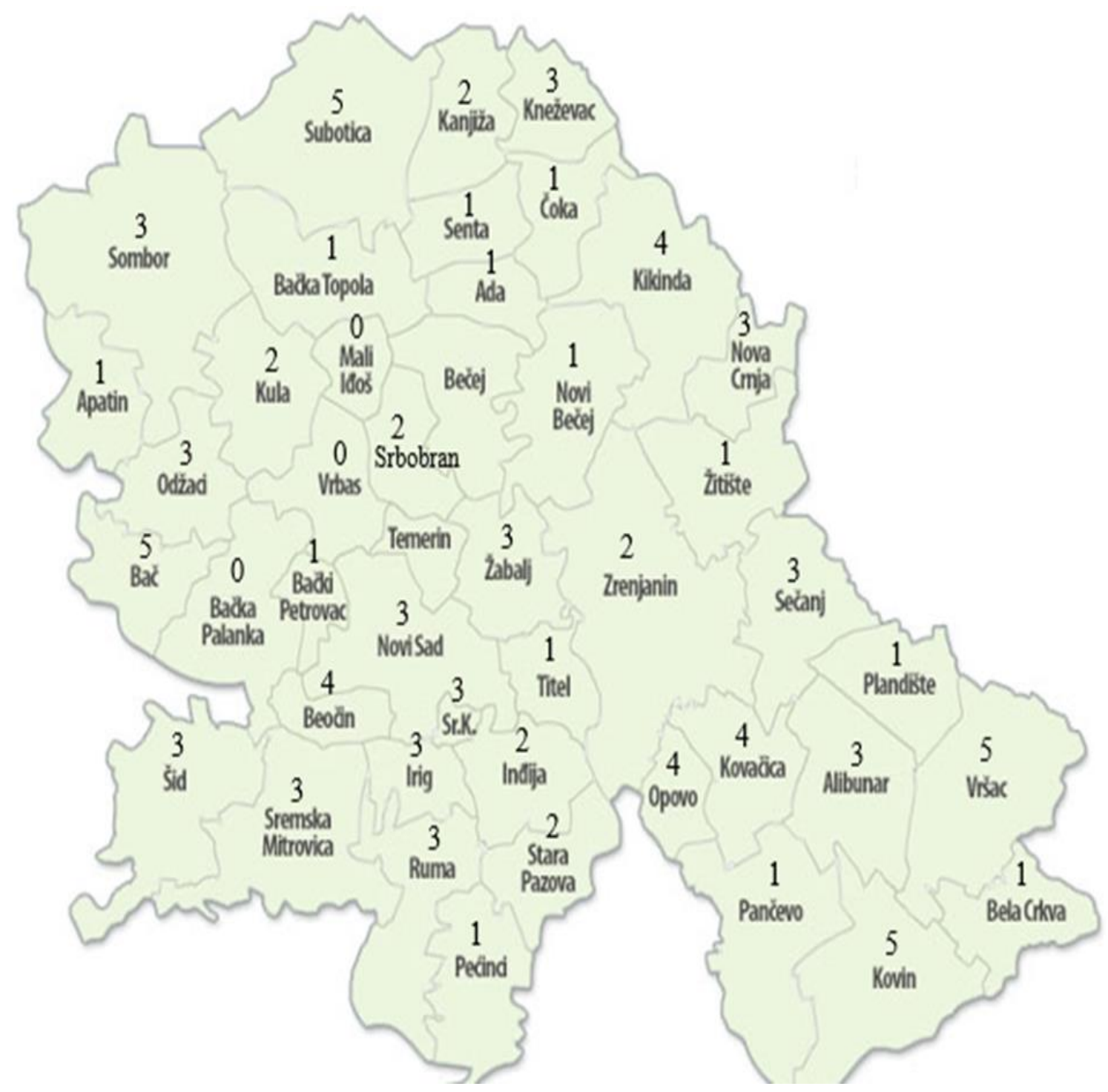

Slika broj 2. Mapa autonomne pokrajine Vojvodina sa prikazom jedinica lokalne samouprave $i$ ocenama istraživača 


\section{Zaključak}

Popis imovine i obaveza mora da sadrži definisane kvalitativne karakteristike da bi uspešno ostvario postavljene ciljeve, a pre svega da bi zaista prikazao stvarno stanje imovine i obaveza. Te karakteristike su tačnost, jasnost i pouzdanost.

Popis kao finalni dokument procesa popisivanja mora da bude tačan i formalno i suštinski. Forma Izveštaja o popisu mora da bude u skladu sa unapred definisanim pravilima sadržanim u zakonskoj regulativi i internim aktima. Svaki izveštaj o popisu mora da sadrži prikaz stvarnog i knjigovodstvenog stanja, utvrđene razlike, kao i preporuke i zapažanja. Takođe sam Izveštaj mora da bude potpisan od strane svih članova komisije. Ukoliko popis ne sadrži verodostojan prikaz stvarnog stanja onda takav popis nema veliku vrednost. Ako popis ispuni samo formalnu tačnost, a ne ispuni suštinsku tačnost, odnosno ako je popis pregledan i uredan, ali ne prikazuje stvarno stanje imovine i obaveza onda popis nije tačan. Isto važi i obrnuto. Ako popis ispuni suštinsku tačnost bez formalne tačnosti, odnosno ako prikazuje stvarno stanje imovine i obaveza, ali na jedan prilično nepregledan i neuredan način, popis opet nije tačan.

Popis imovine i obaveza mora da bude jasan i da pruži što sigurnije uveravanje da prikazuje stvarno stanje imovine i obaveza. Pozicije imovina i obaveza u Izveštaju o popisu moraju biti jasno prikazane, odnosno ne smeju biti potcenjene ni precenjene. One u popisnim listama moraju biti jasno i precizno naznačene. Svaki popis imovine i obaveza treba da svojom pouzdanošću svedoči o tačnosti prikaza stvarnog stanja imovine i obaveza. Da bi popis bio pouzdan on mora prethodno da bude tačan i jasan i mora biti zasnovan na tačnim i jasnim dokazima koji su priloženi uz sam Izveštaj, tako da se svaki čitalac Izveštaja o popisu može uveriti u pouzdanost popisa. Ti dokazi su naturalne i vrednosne popisne liste potpisane od strane svih članova popisne komisije i lica odgovornih za rukovanje imovinom koja se popisuje. To su još Izvodi iz katastra nepokretnosti za sve objekte i zemljišta. Dalje to su Izvodi otvorenih stavki za sve pozicije kupaca i dobavljača u saldu nenaplaćenih potraživanja i neisplaćenih obaveza. Uvidom o sva ova dokumenta svaki zainteresovani čitalac Izveštaja o popisu može se uveriti u njegovu pouzdanost.

Da bi ove karakteristike bile ispunjene popis mora da bude sproveden na način koji neće rezultovati postojanjem nepravilnosti.

Ovim istraživanjem je obuhvaćeno ukupno $22 \%$ celokupne teritorije Srbije i teritorije na kojoj živi $22 \%$ ukupnog stanovništva Republike Srbije prema popisu iz 2011. godine. To je površina od 1.948.748 stanovnika. Oni su veoma važna interesna strana koja bira lica koja su odgovorna za poslovanje direktnih korisnika sredstava budžeta jedinica lokalne samouprave, a to su lica koja su odgovorna i za sprovođenje popisa imovine i obaveza.

Popis imovine i obaveza predstavlja rendgenski snimak imovine i obaveza poslovnog subjekta. On je važan za razumevanje Bilansa stanja i finansijskog položaja preduzeća u meri u kojoj je rendgenski snimak pluća važan za razumevanje položaja i stanja pluća. Bez ispravnog rendgenskog snimka teško da će doktor moći da utvrdi stvarno stanje pluća. Isto važi i za revizora i za poslovnog subjekta, jer teško da će bez popisa moći da utvrde stvarno stanje imovine i obaveza.

$S^{\prime}$ obzirom na činjenicu da Autonomna pokrajina Vojvodina važi za najrazvijeniji deo Srbije i u drugim jedinicama lokalne samouprave van pokrajine se može pretpostaviti da situacija kod sprovođenja popisa imovine i obaveza nije bolja.

Zato je suštinski važno da se popis sprovede na pravilan način. Ako je potrebno jedinice lokalne samouprave treba da organizuju dodatne obuke za svoje zaposlene da bi bolje ovladali tehnikom sprovođenja popisa. Ali za to je potrebno da postoji jasna volja, a ta volja za sada ne postoji.

Krajnji rezultat nakon uspešno završenog popisa treba da predstavlja usaglašenost knjigovodstvenog stanja sa stvarnim stanjem. Time je ispunjen najvažniji cilj popisa i uspostavljena je adekvatna osnova za nastavak poslovanja, vođenja poslovnih knjiga i utvrđivanje relevantnog rezultata poslovanja. Zato svaki subjekt revizije treba da organizuje kratku obuku za članove 
popisne komisije pre početka popisa, a koja bi se odnosila na razumevanje značaja i ciljeva popisa, kao i svih pratećih procedura i načina na koji treba da sprovedu popis svake pozicije ponaosob. Pored obuke koja bi podrazumevala upoznavanje članova popisne komisije sa celokupnom procedurom sprovođenja popisa na pravilan način, angažovanje u popisu treba po okončanju popisa da bude adekvatno nagrađeno. Na taj način zaposleni bi bili motivisaniji i kod njih bi postojala veća želja da prihvate zahtevnost i odgovornost koju popis sa sobom nosi. Ta nagrada ne mora uvek da bude novčana. Ona se može odnositi na dodatne slobodne dane ili u nekom drugom obliku, ali je važno da postoji. Jer ipak u celom procesu popisivanja najvažniji faktor je ljudski faktor. Ukoliko ljudski faktor zakaže, popis će biti loš, koliko god da su dobre procedure i način popisivanja. Ako je ljudski faktor motivisan, adekvatno obučen i odgovoran popis će biti dobar.

Zakonodavac je propustio da u potpunosti na svrsishodan način reguliše oblast popisa imovine i obaveza. Popis imovine i obaveza nije zakonski regulisan na način na koji bi trebalo da bude, čime je ostavljen prostor za proizvoljna tumačenja, različitu primenu i različito sprovođenje popisa u praksi. Postoje zakonski definisani pravilnici o popisu za privredu i korisnike budžetskih sredstava ali oni poseduju ozbiljne nedostatke na svim poljima. Potrebno je jasno definisati predmet popisa. Kada kažemo samo popis imovine i obaveza, to se može tumačiti šarenoliko i proizvoljno sa različitih aspekata. Zato treba jasno definisati koja imovina i koje obaveze podležu popisu i na koji način in treba popisati. Treba definisati obrasce popisnih lista i svih pratećih dokumenata koji će se koristiti prilikom sprovođenja popisa i treba definisati kaznene odredbe za netačno i nepravilno sprovođenje popisa. Tako da kada revizor ili neki drugi oblik kontrole uoči nepravilnosti, tada može da uz osvit na zakonske odredbe u domenu kaznenih odredbi dodatno motiviše i podstakne subjekta da popis sprovodi na pravilan način. Samo na ovaj način može se postići jednoobraznost i sveobuhvatnost popisa uz poštovanje specifičnosti svakog subjekta, čime bi revidiranje popisa bilo celishodnije. Zato je preporuka zakonodavcu da jasno reguliše oblast popisa imovine i obaveza.

\section{Bibliografija}

[1] Pravilnik o načinu i rokovima vršenja popisa imovine i obaveza korisnika budžetskih sredstava Republike Srbije i usklađivanja knjigovodstvenog stanja sa stvarnim stanjem („Službeni glasnik RS", br. 33/2015 i 101/2018);

[2] Uputstvo o organizaciji i računovodstvenom obuhvatanju popisa imovine i obaveza budžetskih korisnika uključenih u konsolidovani račun trezora Autonomne pokrajine Vojvodine date na korišćenje drugim pravnim licima ("Službeni list AP Vojvodine", br. 49/2014, 51/2014, 3/2015 i 48/2015);

[3] Uredba o budžetskom računovodstvu ("Službeni glasnik RS", br. 125/2003, 12/2006 i 27/2020);

[4] Zakon o budžetskom sistemu ("Službeni glasnik RS", br. 54/2009, 73/2010...72/2019);

[5] Časopis „Poresko pravni instruktor”, broj 127, Beograd, 2019. godina, članak: predmet popisa;

[6] Časopis „Računovodstvena praksa" 21-22/2019, članci: popis nekretnina, postrojenja i opreme; popis zaliha; popis obaveza;

[7] Časopis „REVIZOR" novembar 2019, Informativno-poslovni centar d.o.o. Beograd, Višegradska 6/II, Beograd, članak: popis imovine i obaveza na dan 31.12.2019.

[8] www.dri.rs 